University of Wollongong

Research Online

Australian Institute for Innovative Materials -

Papers

Australian Institute for Innovative Materials

$1-1-2016$

General synthesis of porous mixed metal oxide hollow spheres with enhanced supercapacitive properties

Qinghong Wang

University of Wollongong, qwang@uow.edu.au

Yuxuan Zhu

Xuzhou Normal University

Jing Xue

Xuzhou Normal University

Xinsheng Zhao

Jiangsu Normal University

Zaiping Guo

University of Wollongong, zguo@uow.edu.au

See next page for additional authors

Follow this and additional works at: https://ro.uow.edu.au/aiimpapers

Part of the Engineering Commons, and the Physical Sciences and Mathematics Commons

Research Online is the open access institutional repository for the University of Wollongong. For further information contact the UOW Library: research-pubs@uow.edu.au 


\title{
General synthesis of porous mixed metal oxide hollow spheres with enhanced supercapacitive properties
}

\author{
Abstract \\ Porous mixed metal oxide (MMO) hollow spheres present high specific surface areas, abundant \\ electrochemically active sites, and outstanding electrochemical properties, showing potential \\ applications in energy storage. A hydro/solvothermal process, followed by a calcination process, can be a \\ viable method for producing uniform porous metal oxide hollow spheres. Unfortunately, this method \\ usually involves harsh synthetic conditions such as high temperature and intricate processing. Herein, we \\ report a general and facile "ion adsorption-annealing" approach for the fabrication of uniform porous \\ MMO hollow spheres. The size and shell thickness of the as-obtained hollow spheres can be adjusted by \\ the carbohydrate sphere templates and the solution concentration. Electrochemical measurements of the \\ MMO hollow spheres demonstrate excellent supercapacitive properties, which may be due to the small \\ size, ultrathin shells, and fine porous structure. \\ Disciplines \\ Engineering | Physical Sciences and Mathematics

\section{Publication Details} \\ Wang, Q., Zhu, Y., Xue, J., Zhao, X., Guo, Z. \& Wang, C. (2016). General synthesis of porous mixed metal \\ oxide hollow spheres with enhanced supercapacitive properties. ACS Applied Materials and Interfaces, 8 \\ (27), 17226-17232.
}

\section{Authors}

Qinghong Wang, Yuxuan Zhu, Jing Xue, Xinsheng Zhao, Zaiping Guo, and Chao Wang 


\section{General Synthesis of Porous Mixed Metal Oxide}

\section{Hollow Spheres with Enhanced Supercapacitive}

\section{Properties}

Qinghong Wang, ${ }^{+\neq}$Yuxuan Zhu, ${ }^{\dagger}$ Jing Xue,${ }^{\dagger}$ Xinsheng Zhao, ${ }^{\S}$ Zaiping Guo,,${ }^{*}$ ' and Chao Wang ${ }^{*}$,

${ }^{\dagger}$ School of Chemistry and Chemical Engineering, Jiangsu Key Laboratory of Green Synthetic Chemistry for Functional Materials, Jiangsu Normal University, Xuzhou, Jiangsu 221116, China Institute for Superconducting \& Electronic Materials, University of Wollongong, Wollongong, NSW 2522, Australia

${ }^{\S}$ Hydrogen energy laboratory, School of Physics and Electronic Engineering, Jiangsu Normal University, Xuzhou, Jiangsu 221116, China

KEYWORDS: Mixed metal oxides, Porous hollow spheres, Ion adsorption-annealing process, Electrochemical properties, Supercapacitor

ABSTRACT: Porous mixed metal oxide (MMO) hollow spheres present high specific surface areas, abundant electrochemically active sites and outstanding electrochemical properties, showing potential applications in energy storage. A hydro/solvothermal process followed by a calcination process can be a viable method for producing uniform porous metal oxide hollow spheres. Unfortunately, this method usually involves harsh synthetic conditions such as high temperature and intricate processing. Herein, we report a general and facile "ion adsorption- 
annealing" approach for the fabrication of uniform porous MMO hollow spheres. The size and shell thickness of the as-obtained hollow spheres can be adjusted by the carbohydrate sphere templates and the solution concentration. Electrochemical measurements of the MMO hollow spheres demonstrate excellent supercapacitive properties, which may be due to the small size, ultrathin shells and fine porous structure.

\section{INTRODUCTION}

Transition metal oxides have been considered to be promising electrode materials for energy storage devices such as electrochemical capacitors (ECs), fuel cells (FCs) and lithium ion batteries (LIBs). Among them, cobalt oxides exhibit outstanding anodic performance. ${ }^{1-4}$ Nevertheless they often suffer from high cost and toxicity, as well as poor conductivity. To solve these problems, much effort is being directed towards the fabrication of cheap and eco-friendly mixed metal oxides (MMOs) like $\mathrm{ZnCo}_{2} \mathrm{O}_{4},{ }^{5-7} \mathrm{NiFe}_{2} \mathrm{O}_{4},{ }^{8-10} \mathrm{Zn}_{2} \mathrm{SnO}_{4}$ and $\mathrm{ZnSnO}_{3}{ }^{11,12}$ Due to their complex chemical compositions, as well as the synergetic effects between two metals, MMO present higher electrochemical activity than their corresponding single metal oxides. ${ }^{13-16}$ Unfortunately, poor conductivity and structural collapse are still severe weakness that limit full electrochemical reactions, resulting in fast capacity decay. Many approaches, such as controlling nanostructures $^{17-20}$ and synthesizing $\mathrm{MMO} / \mathrm{Ni}$ substrates $^{21-23}$ and $\mathrm{MMO} /$ carbon hybrids $^{24-26}$ have been developed to further improve their electrochemical performance.

Hollow spheres, especially those with porous nanostructures, have attracted numerous research efforts in the energy storage field. Compared with the same-sized solid nanomaterials, hollow spheres deliver short ion diffusion paths, abundant active sites for reactions, and plentiful buffer space to accommodate volume changes during charge-discharge processes. ${ }^{27-29}$ In recent years, much effort has been directed towards exploring effective strategies for the fabrication of 
porous hollow spheres. Using carbohydrate spheres (CSs) as hard templates has been a popular method to prepare hollow spheres because they are simple in preparation yet effective in morphology controlling. ${ }^{30,31}$ Zhang et al. prepared hollow mixed metal oxides with multiple shells by a "penetration-solidification-annealing" process. ${ }^{32}$ The solidification process was carried out at $170{ }^{\circ} \mathrm{C}$ by refluxing to obtain M-glycolate-CSs precursor. Tian et al. prepared hollow $\mathrm{ZnO}$ by a hydrothermal process to obtain $\mathrm{Zn}$-CSs precursor and a following annealing process to obtain $\mathrm{ZnO}$ product. ${ }^{33}$ It should be noted that both the refluxing process and the hydrothermal process employed to obtain the M-CSs precursor suffer from high temperature and complicated processing. So, a facile and general strategy for fabricating porous MMO hollow spheres is highly desirable.

To solve this problem, we have developed a facile and general "ion adsorption-annealing" method which involves an ion adsorption process to prepare M-M-CSs precursor, combined with a subsequent calcination process to synthesize uniform porous MMO hollow spheres. In this method, the ion adsorption process was carried out at room temperature without any complex agents, precipitants, or surfactants, which makes it quite simple. Furthermore, the hollow structure, thin shell, and porosity endow the MMO samples with high specific surface area, good ion/electron transport properties, and volume buffer capability, which are all beneficial to the high discharge capacitance, excellent rate performance and long cycle life.

\section{EXPERIMENTAL METHODS}

\subsection{Synthesis}

The carbohydrate spheres template was prepared by the polymerization reaction of glucose under hydrothermal conditions at $180^{\circ} \mathrm{C}$ for $10 \mathrm{~h}$. 
Synthesis of porous $\mathrm{ZnCo}_{2} \mathrm{O}_{4}$ hollow spheres. For the synthesis of porous $\mathrm{ZnCo}_{2} \mathrm{O}_{4}$ hollow spheres, $0.05 \mathrm{~g}$ of freshly-prepared CSs were dispersed into $50 \mathrm{ml}$ of deionized water containing $0.04 \mathrm{~mol}$ of $\mathrm{Co}\left(\mathrm{NO}_{3}\right)_{2} \cdot 6 \mathrm{H}_{2} \mathrm{O}$ and $0.02 \mathrm{~mol}$ of $\mathrm{Zn}\left(\mathrm{NO}_{3}\right)_{2} \cdot 6 \mathrm{H}_{2} \mathrm{O}$ by sonication. After ultrasonic dispersion for $2 \mathrm{~h}$, the resulting suspension was stirred for $12 \mathrm{~h}$ at $25{ }^{\circ} \mathrm{C}$. Then, the $\mathrm{Zn}$-Co-CSs precursor was obtained after filtration, washed with DI water and dried at $60{ }^{\circ} \mathrm{C}$ overnight. Finally, the precursor was heated in air at $450{ }^{\circ} \mathrm{C}$ for $2 \mathrm{~h}$ with a heating rate of $1{ }^{\circ} \mathrm{C} \min ^{-1}$ to synthesize the porous $\mathrm{ZnCo}_{2} \mathrm{O}_{4}$ hollow spheres.

Synthesis of porous $\mathrm{NiFe}_{2} \mathrm{O}_{4}$ hollow spheres. $0.05 \mathrm{~g}$ of freshly-prepared CSs, $0.04 \mathrm{~mol}$ of $\mathrm{Fe}\left(\mathrm{NO}_{3}\right)_{3} \cdot 9 \mathrm{H}_{2} \mathrm{O}$ and $0.02 \mathrm{~mol}$ of $\mathrm{Ni}\left(\mathrm{NO}_{3}\right)_{2} \cdot 6 \mathrm{H}_{2} \mathrm{O}$ were used as the raw materials, while the other conditions were the same as the above procedure.

Synthesis of porous $\mathrm{ZnSnO}_{3}$ hollow spheres. For the synthesis of porous $\mathrm{ZnSnO}_{3}$ hollow spheres, $0.03 \mathrm{~mol}$ of $\mathrm{SnCl}_{4} \cdot 5 \mathrm{H}_{2} \mathrm{O}$ and $0.03 \mathrm{~mol}$ of $\mathrm{Zn}\left(\mathrm{NO}_{3}\right)_{2} \cdot 6 \mathrm{H}_{2} \mathrm{O}$ were used as the sources of cations and absolute ethanol was used as the solvent, while the other conditions were the same as the preparation process of $\mathrm{ZnCo}_{2} \mathrm{O}_{4}$ and $\mathrm{NiFe}_{2} \mathrm{O}_{4}$.

\subsection{Materials characterization}

Crystallographic information of the as-prepared precursors and MMO products was obtained by powder X-ray diffraction (XRD) analysis using a Rigaku D/Max-2500 with $\mathrm{Cu} \mathrm{K} \alpha$ radiation $(\lambda=0.15418 \mathrm{~nm})$. The morphologies and structures of the as-prepared MMO hollow spheres were investigated by scanning electron microscopy (SEM, JEOL JSM-6700F), transmission electron microscope (TEM) and high-resolution TEM (HRTEM, Tecnai G2 F20). The element analysis of the as-obtained samples was evaluated using an energy dispersive X-ray spectroscopy (EDS, Oxford ISIS300). Thermogravimetric analysis (TGA) of the as-prepared Zn-Co-CSs precursor was conducted in air up to $700{ }^{\circ} \mathrm{C}$ on a Q5000 thermal analyzer (TA Instruments). Nitrogen 
adsorption-desorption isotherms of the MMO hollow spheres were carried out at $77 \mathrm{~K}$ on a Quantachrome Autosorb-IQ2 analyzer. Specific surface areas of the samples were measured by Brunauer-Emmett-Teller analysis.

\subsection{Electrochemical measurements}

The working electrodes were fabricated from viscous slurry containing active materials ( 80 $\mathrm{wt} \%$ ), acetylene black $(10 \mathrm{wt} \%)$ and polyvinylidene fluoride (PVDF, $10 \mathrm{wt} \%$ ) in $\mathrm{N}-$ methylpyrrolidinone (NMP). Then the obtained slurry was pasted onto $1 \mathrm{~cm} \times 1 \mathrm{~cm}$ current collectors. The average loading mass was about $3 \mathrm{mg} \mathrm{cm}^{-2}$. For electrochemical measurements, a three-electrode cell was fabricated using a Pt plate as the counter electrode and $\mathrm{Hg} / \mathrm{HgO}$ electrode as the reference electrode. For $\mathrm{ZnCo}_{2} \mathrm{O}_{4}$ and $\mathrm{NiFe}_{2} \mathrm{O}_{4}$ electrodes, a $2 \mathrm{M} \mathrm{KOH}$ aqueous solution was used as electrolyte. For $\mathrm{ZnSnO}_{3}$ electrode, a $1 \mathrm{M} \mathrm{Na}_{2} \mathrm{SO}_{4}$ aqueous solution was the electrolyte. Electrochemical properties of the electrodes were characterized by galvanostatic charge-discharge measurements (LAND battery test instrument) at various current densities and cyclic voltammetry (CV, CHI600e electrochemical workstation) tests at different scan rates. An asymmetric supercapacitor (ASC) is constructed using $\mathrm{ZnCo}_{2} \mathrm{O}_{4}$ electrode as the positive electrode, active carbon electrode as the negative electrode and a $2 \mathrm{M} \mathrm{KOH}$ aqueous solution as electrolyte. The two electrodes were separated using a polypropylene sheet. All electrochemical tests were performed at room temperature.

The specific capacitance $\mathrm{C}\left(\mathrm{F} \mathrm{g} \mathrm{g}^{-1}\right)$ was derived from galvanostatic charge-discharge curves using Eq. (1):

$$
C=\frac{I \Delta t}{m \Delta V}
$$


where $I(\mathrm{~A}), \Delta t(\mathrm{~s}), m(\mathrm{~g})$ and $\Delta V(\mathrm{~V})$ represent the charge/discharge current, the discharge time, the mass of electroactive material and the working voltage window, respectively. The energy density $E\left(\mathrm{Wh} \mathrm{kg}^{-1}\right)$ and power density $P\left(\mathrm{~W} \mathrm{~kg}^{-1}\right)$ is calculated from the following formulas:

$$
\begin{aligned}
& E=\frac{1}{2} C_{\text {cell }} \Delta V^{2} \\
& P=\frac{E}{\Delta t}
\end{aligned}
$$

where $C_{\text {cell }}\left(\mathrm{F} \mathrm{g}^{-1}\right)$ is the specific capacitance of the ASC device, $\Delta V(\mathrm{~V})$ indicates the working potential window and $\Delta t(\mathrm{~s})$ denotes the time for full discharge.

\section{RESULTS AND DISCUSSION}

\subsection{Material characterization and probable formation mechanism}

The "ion adsorption-annealing" process for porous MMO hollow spheres is illustrated in Scheme 1. First, CSs about $400 \mathrm{~nm}$ in diameter with smooth surfaces were synthesized (Figure $\mathrm{S} 1$, Figure S2a and S2b). It is well-known that abundant oxygenic functional groups, such as $\mathrm{C}=\mathrm{O}, \mathrm{COOH}$ and $\mathrm{OH}$, are exposed on freshly-prepared $\mathrm{CSs}$, which could adsorb metal cations by electrostatic adsorption to form M-M-CSs precursor, ${ }^{30,31,34}$ which shows a rougher surface than the CSs (Figure S2c and S2d). The metal cations absorbed on CSs were then annealed at a certain temperature to remove the CSs templates, and uniform MMO hollow spheres with fine porous structures were obtained. The thermal properties of the M-M-CSs precursor were investigated via TGA to explore the crystallization temperature of $\mathrm{MMO}$ and the temperature for the removal of CSs. For Zn-Co-CSs precursor, the thermal decomposition consists of two steps (Figure S3). The first stage below $200{ }^{\circ} \mathrm{C}$ may be mainly resulted from the removal of physically adsorbed water. While the second stage between 200 and $400{ }^{\circ} \mathrm{C}$ is ascribed to the degradation of CSs coupled with the formation of $\mathrm{ZnCo}_{2} \mathrm{O}_{4}$. Thus, $450{ }^{\circ} \mathrm{C}$ was set as the calcination temperature for the transformation from $\mathrm{Zn}-\mathrm{Co}-\mathrm{CSs}$ precursor to porous $\mathrm{ZnCo}_{2} \mathrm{O}_{4}$ hollow spheres. 


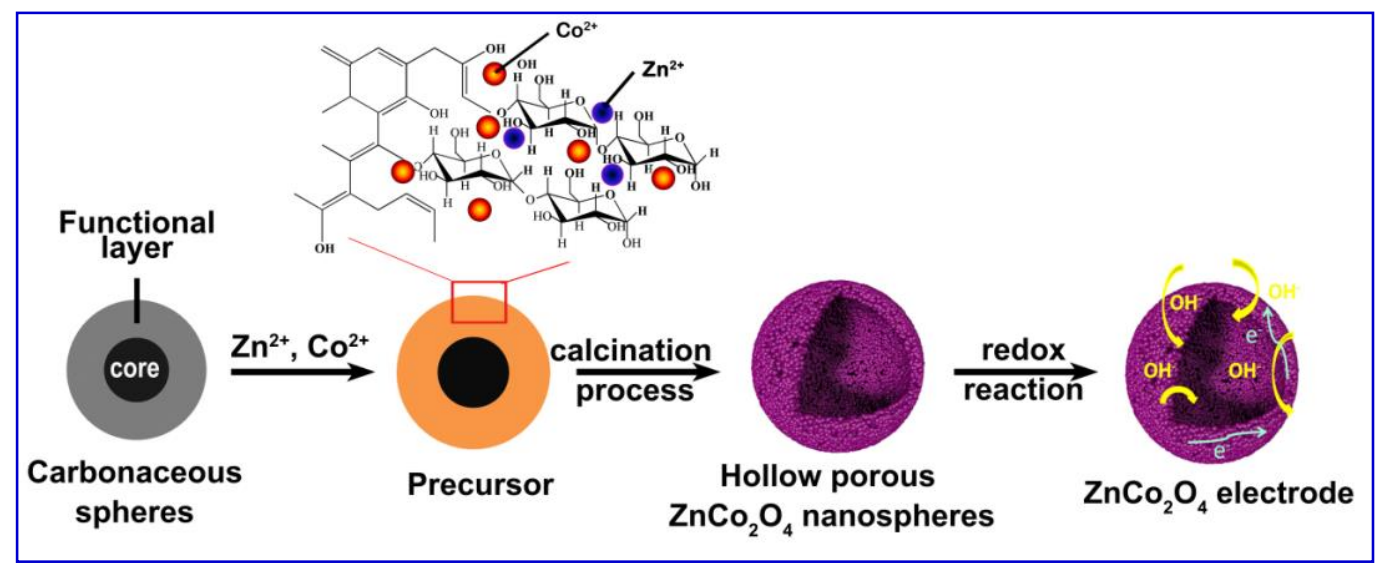

Scheme 1. Scheme for the synthesis and energy storage process for the as-prepared porous MMO hollow spheres $\left(\mathrm{ZnCo}_{2} \mathrm{O}_{4}\right.$ as an example).

The crystal structure and morphology of the as-obtained porous $\mathrm{ZnCo}_{2} \mathrm{O}_{4}, \mathrm{NiFe}_{2} \mathrm{O}_{4}$ and $\mathrm{ZnSnO}_{3}$ hollow spheres were characterized by XRD, SEM and TEM. Figure 1a exhibits the XRD pattern of the $\mathrm{ZnCo}_{2} \mathrm{O}_{4}$ product. All diffraction peaks can be attributed to cubic $\mathrm{ZnCo}_{2} \mathrm{O}_{4}$ phase with lattice constants of $\mathrm{a}=\mathrm{b}=\mathrm{c}=8.095 \AA$ (space group Fd3m, JCPDS 23-1390). So it is confirmed that after calcination at $450{ }^{\circ} \mathrm{C}, \mathrm{Zn}$-Co-CSs precursor is fully transferred into $\mathrm{ZnCo}_{2} \mathrm{O}_{4}$ with high purity and good crystallinity. An SEM image displayed in Figure $1 \mathrm{~b}$ reveals that the $\mathrm{ZnCo}_{2} \mathrm{O}_{4}$ sample is mainly composed of uniform hollow spheres about $200 \mathrm{~nm}$ in diameter. It is noted that the size of $\mathrm{ZnCo}_{2} \mathrm{O}_{4}$ is smaller than that of the $\mathrm{Zn}$-Co-CSs precursor, indicating that the spheres have become slightly shrunken during the transformation process from the precursor to $\mathrm{ZnCo}_{2} \mathrm{O}_{4}$. Moreover, it is observed that the surface of the $\mathrm{ZnCo}_{2} \mathrm{O}_{4}$ microspheres is made up of many sintered $\mathrm{ZnCo}_{2} \mathrm{O}_{4}$ nanoparticles with the size of tens of nanometers. The hollow feature is further confirmed by the TEM results shown in Figure 1c. Further TEM analysis (Figure 1d) reveals that the $\mathrm{ZnCo}_{2} \mathrm{O}_{4}$ spheres possess an ultrathin shell (about $20 \mathrm{~nm}$ in thickness) composed of nanoparticles about several nanometers in size, among which numerous mesopores have been 
generated. TEM images clearly show the porous structure of the $\mathrm{ZnCo}_{2} \mathrm{O}_{4}$ spheres, which may be caused by rapid mass transport through the shell during calcination. A more detailed HRTEM image shown in Figure 1e presents clear lattice fringes with interplanar distances of $0.24 \mathrm{~nm}$, $0.29 \mathrm{~nm}$ and $0.47 \mathrm{~nm}$, corresponding to the (311), (220) and (111) planes of spinel $\mathrm{ZnCo}_{2} \mathrm{O}_{4}$, respectively. It is observed that the selected area electron diffraction (SAED) pattern displays well-defined rings (Figure 1f), demonstrating the polycrystalline nature of the $\mathrm{ZnCo}_{2} \mathrm{O}_{4}$ hollow spheres. Moreover, the molar ratio of $\mathrm{Zn:}$ Co: $\mathrm{O}$ from the EDS spectrum (Figure S4) is $\sim 1: 2: 4$ within the samples, further confirming the formation of $\mathrm{ZnCo}_{2} \mathrm{O}_{4}$ pure phase. The porosity and specific surface area of the $\mathrm{ZnCo}_{2} \mathrm{O}_{4}$ hollow spheres were characterized by $\mathrm{N}_{2}$ adsorption/desorption isotherms and pore size distribution measurements. Figure $2 \mathrm{~b}$ exhibits a pore size distribution in the range of 2 to $5 \mathrm{~nm}$, which agrees well with what can be observed in the TEM images. It is calculated that the pore volume is $0.44 \mathrm{~cm}^{3} \mathrm{~g}^{-1}$. Remarkably, the porous $\mathrm{ZnCo}_{2} \mathrm{O}_{4}$ hollow spheres display a specific surface area of $172.62 \mathrm{~m}^{2} \mathrm{~g}^{-1}$. 

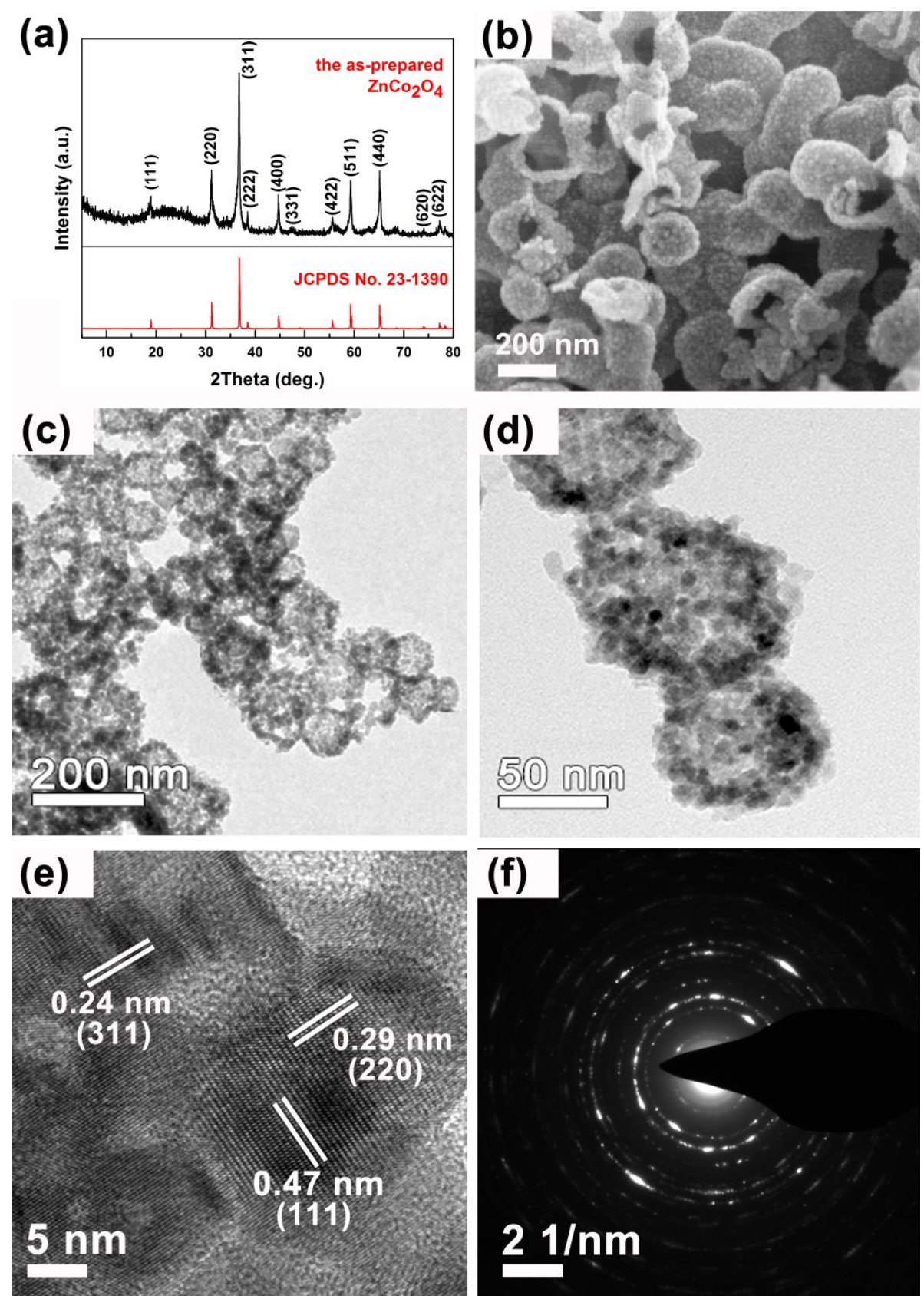

Figure 1. (a) XRD pattern, (b) SEM image, (c, d) low-magnification TEM images, (e) HRTEM image and (f) corresponding SAED pattern of the as-prepared porous $\mathrm{ZnCo}_{2} \mathrm{O}_{4}$ hollow spheres. 

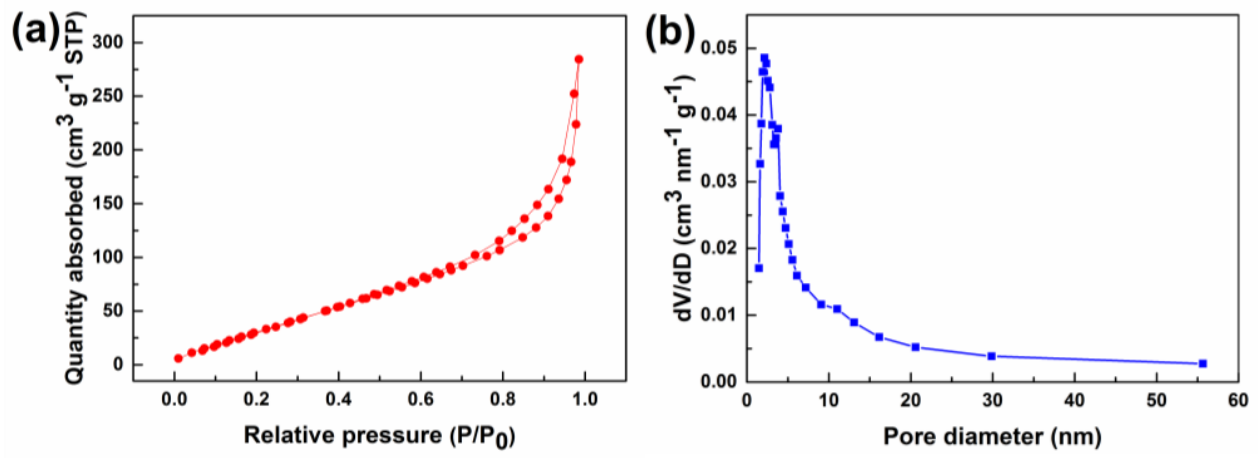

Figure 2. (a) Nitrogen adsorption-desorption isotherm and (b) the corresponding pore size distribution of the as-prepared porous $\mathrm{ZnCo}_{2} \mathrm{O}_{4}$ hollow spheres.

Figure $3 \mathrm{a}$ shows the XRD pattern of the as-obtained $\mathrm{NiFe}_{2} \mathrm{O}_{4}$ hollow spheres. It can be seen that all the diffraction peaks can be indexed to cubic $\mathrm{NiFe}_{2} \mathrm{O}_{4}$ phase with the lattice constants of $\mathrm{a}=\mathrm{b}=\mathrm{c}=8.339 \AA$ (space group Fd3m, JCPDS 10-325), without any detectable impurity. An SEM image (Figure 3b) reveals the high quality of the homogeneous and uniform $\mathrm{NiFe}_{2} \mathrm{O}_{4}$ hollow spheres, with a particle size of about $250 \mathrm{~nm}$. The TEM images in Figure $3 \mathrm{c}$ and $3 \mathrm{~d}$ further confirm the hollow and porous structure of the as-prepared $\mathrm{NiFe}_{2} \mathrm{O}_{4}$ sample. The shells of the $\mathrm{NiFe}_{2} \mathrm{O}_{4}$ hollow spheres are about $20 \mathrm{~nm}$ in thickness, which are also composed of nanoparticles. HRTEM image (Figure 3e) demonstrates that individual $\mathrm{NiFe}_{2} \mathrm{O}_{4}$ nanoparticle has uniform lattice fringes. The lattice spacing is calculated to be $0.25 \mathrm{~nm}$ and $0.29 \mathrm{~nm}$, which agrees well with the (311) and (220) planes of the $\mathrm{NiFe}_{2} \mathrm{O}_{4}$ (JCPDS No. 10-325). The SAED pattern (Figure 3f) shows well-defined rings, indicating that the as-prepared $\mathrm{NiFe}_{2} \mathrm{O}_{4}$ hollow spheres are polycrystalline. Moreover, we have prepared $\mathrm{ZnSnO}_{3}$ (JCPDS No. 28-1486) with porous structure by the same method (Figure 4a). From the SEM, TEM and HRTEM images (Figure 4b4e), it can be seen that the porous $\mathrm{ZnSnO}_{3}$ is also composed of hollow spheres with thin shells, which are constructed from nanoparticles about $10 \mathrm{~nm}$ in diameter. The corresponding SAED pattern (figure 4f) also demonstrates the polycrystalline characteristic of the porous $\mathrm{ZnSnO}_{3}$ 
hollow spheres. Furthermore, it is found that the obtained $\mathrm{NiFe}_{2} \mathrm{O}_{4}$ and $\mathrm{ZnSnO}_{3}$ hollow spheres both present a pore size distribution ranging from 2 to $5 \mathrm{~nm}$ (Figure S5), as well as high surface area of $156.35 \mathrm{~m}^{2} \mathrm{~g}^{-1}$ and $137.91 \mathrm{~m}^{2} \mathrm{~g}^{-1}$, respectively.
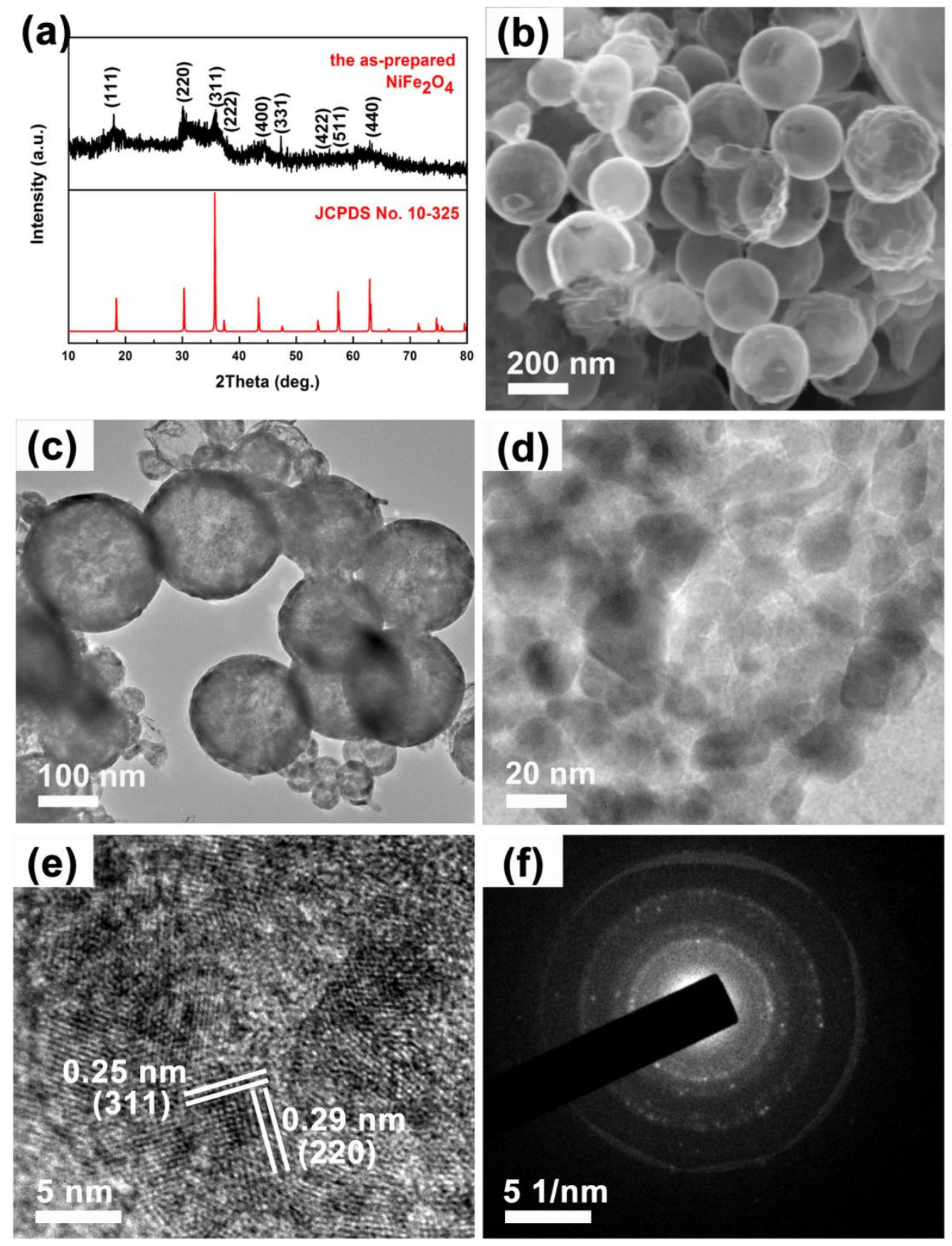

Figure 3. (a) XRD pattern, (b) SEM image, (c, d) low-magnification TEM images, (e) HRTEM image and (f) corresponding SAED pattern of the as-prepared porous $\mathrm{NiFe}_{2} \mathrm{O}_{4}$ hollow spheres. 
(a)
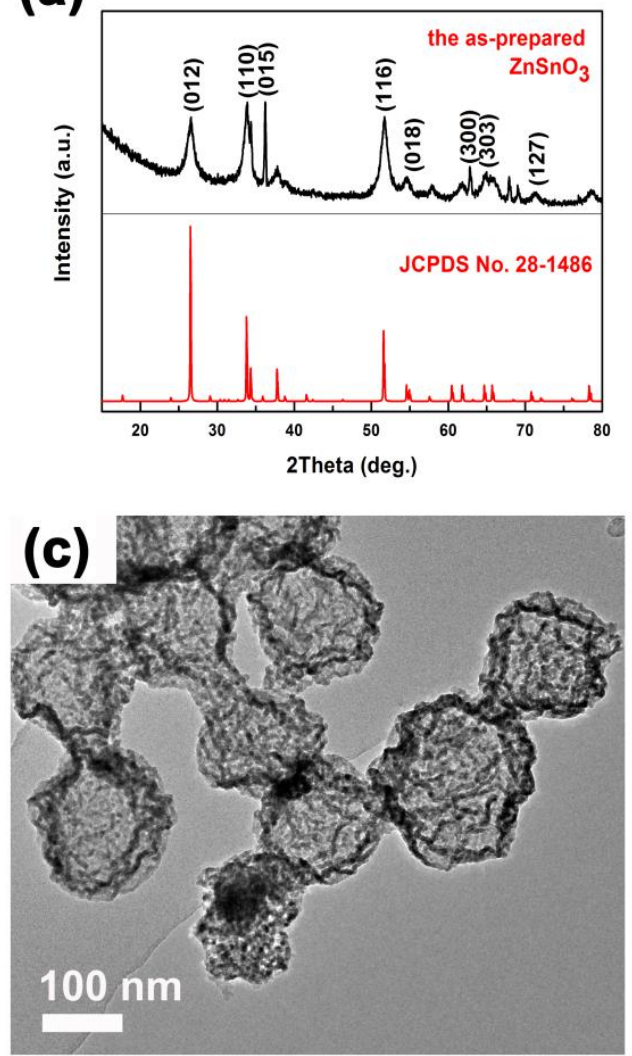

(e)

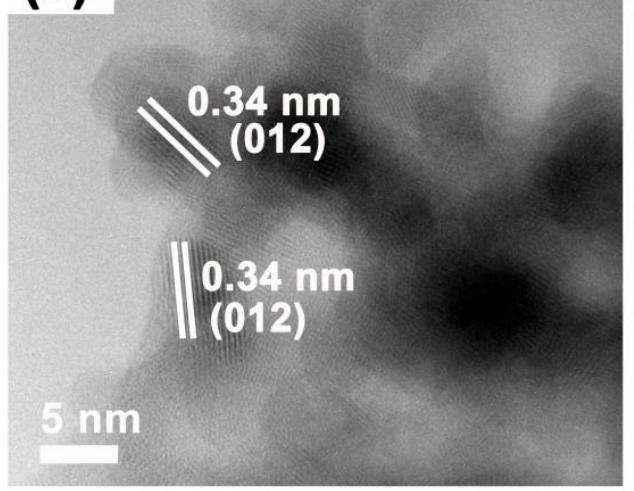

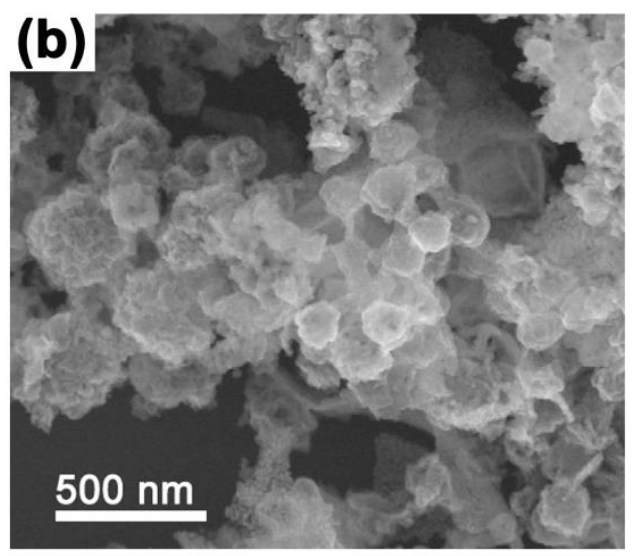

(d)

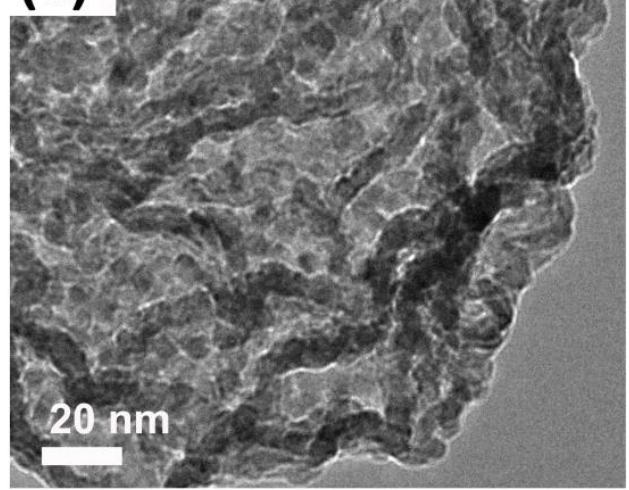

(f)

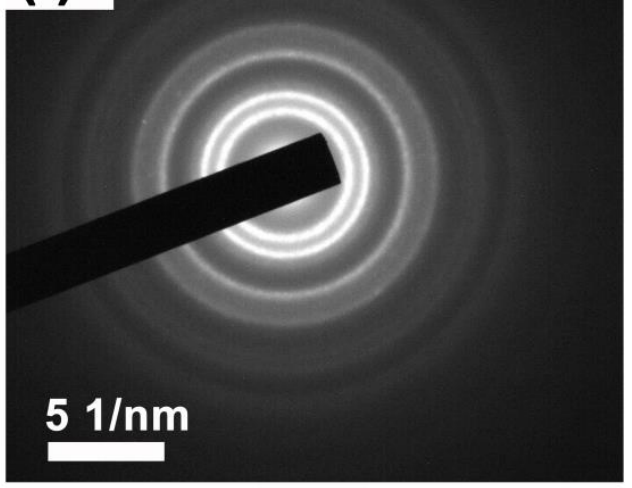

Figure 4. (a) XRD pattern, (b) SEM image, (c, d) low-magnification TEM images, (e) HRTEM image and (f) corresponding SAED pattern of the as-prepared porous $\mathrm{ZnSnO}_{3}$ hollow spheres.

All in all, the MMO samples prepared by this method are composed of small hollow spheres with thin and porous shells, which ensure large electrode/electrolyte contact area, abundant 
electroactive sites and fast electron/ion transport rate for electrochemical reactions, demonstrating their potential applications in some novel electronic devices. Herein, the supercapacitive properties of the as-prepared porous $\mathrm{ZnCo}_{2} \mathrm{O}_{4}, \mathrm{NiFe}_{2} \mathrm{O}_{4}$ and $\mathrm{ZnSnO}_{3}$ hollow spheres are investigated.

\subsection{Supercapacitive performances}

The supercapacitive properties of the MMO electrodes were evaluated in a three-electrode configuration. $\mathrm{CV}$ and galvanostatic charge-discharge measurements of the $\mathrm{ZnCo}_{2} \mathrm{O}_{4}$ electrode were performed in $2 \mathrm{M} \mathrm{KOH}$. The representative $\mathrm{CV}$ profiles of $\mathrm{ZnCo}_{2} \mathrm{O}_{4}$ at different sweep rates of 5 50 mV s${ }^{-1}$ are shown in Figure 5a. All the CV curves present a pair of well-defined redox peaks, which are distinctly different from those of electrical double layer capacitors (EDLCs), indicating that the electrochemical capacitance mainly originates from Faradaic redox reactions. The reversible conversion in accordance with the well-defined redox peaks may be described as follows: $:^{21,22}$

$$
\begin{aligned}
& \mathrm{Co}_{2} \mathrm{O}_{4}^{2-}+2 \mathrm{H}_{2} \mathrm{O} \leftrightarrow 2 \mathrm{CoOOH}+2 \mathrm{OH}^{-} \\
& \mathrm{CoOOH}+\mathrm{H}_{2} \mathrm{O}+e^{-} \leftrightarrow \mathrm{Co}(\mathrm{OH})_{2}+\mathrm{OH}^{-}
\end{aligned}
$$

Galvanostatic charge-discharge behaviors of the $\mathrm{ZnCo}_{2} \mathrm{O}_{4}$ material were investigated at different current densities of $1 \sim 10 \mathrm{~A} \mathrm{~g}^{-1}$ within $0 \sim 0.55 \mathrm{~V}$ (vs. $\mathrm{Hg} / \mathrm{HgO}$ ). The nonlinear chargedischarge curves present in Figure $5 \mathrm{~b}$ clearly demonstrate the occurrence of typical Faradaic redox reactions, further confirming the pseudo-capacitance behavior of the $\mathrm{ZnCo}_{2} \mathrm{O}_{4}$ electrode, which agrees well with the CV results. The specific capacitances calculated from chargedischarge tests are $1158,1006,925$ and $845 \mathrm{~F} \mathrm{~g}^{-1}$ at $1,2,5$ and $10 \mathrm{~A} \mathrm{~g}^{-1}$, respectively (Figure 5c). When the current density increases to $10 \mathrm{~A} \mathrm{~g} \mathrm{~g}^{-1}$, the capacitance still retains $73 \%$ of the capacitance at $1 \mathrm{~A} \mathrm{~g}^{-1}$. These results suggest good rate capability of the $\mathrm{ZnCo}_{2} \mathrm{O}_{4}$ electrode. 

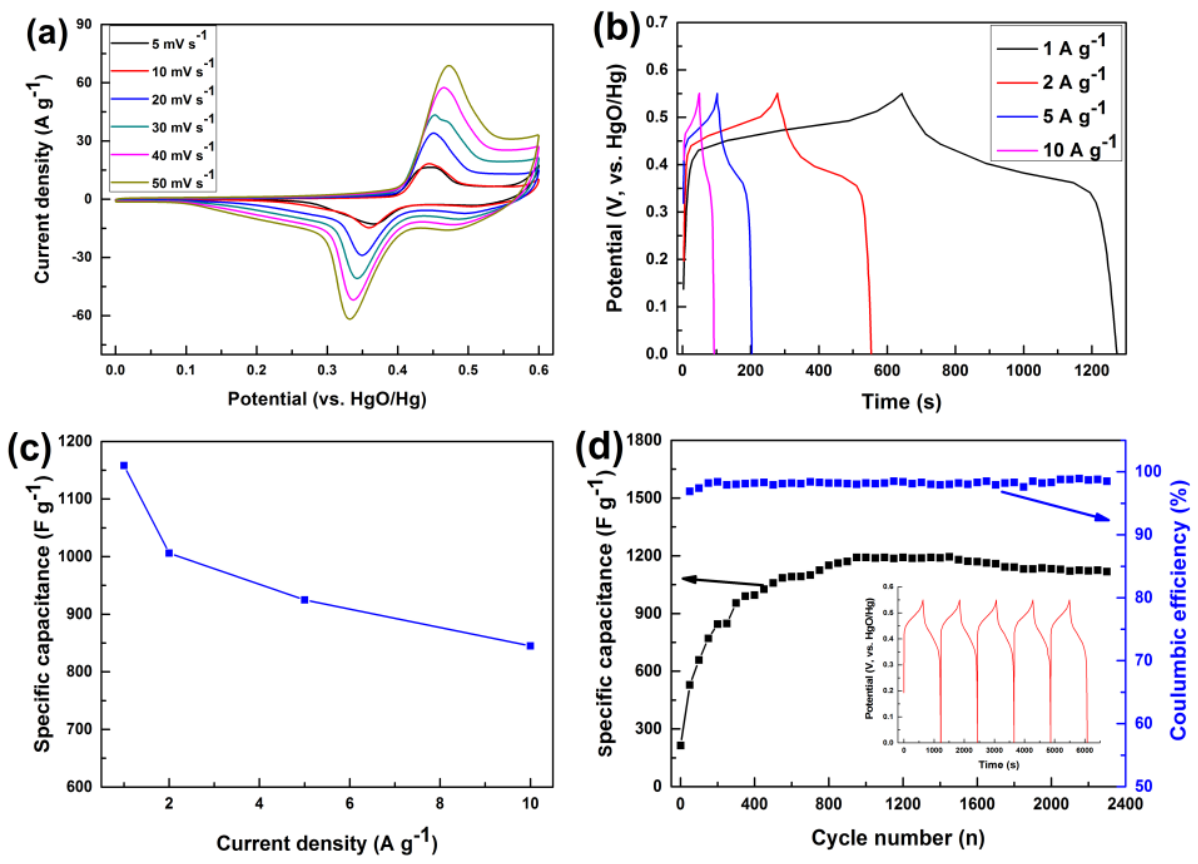

Figure 5. Electrochemical properties of the porous $\mathrm{ZnCo}_{2} \mathrm{O}_{4}$ hollow spheres electrode in a threeelectrode measurement system. (a) $\mathrm{CV}$ curves at various sweep rates between 0 and $0.6 \mathrm{~V}$ (vs. $\mathrm{Hg} / \mathrm{HgO}$ ). (b) Galvanostatic charge-discharge curves with different currents. (c) Specific capacitance as a function of current density. (d) Cycling performance and coulombic efficiency at $1 \mathrm{~A} \mathrm{~g}^{-1}$. The inset in (d) presents the charge-discharge curves of the last 5 cycles.

Cycling stability and energy deliverable efficiency are also critical parameters for supercapacitors. As shown in Figure 5d, the Coulombic efficiency is as high as $98 \%$ even after 2300 charge-discharge cycles, demonstrating excellent kinetic reversibility and good cycling stability of the porous $\mathrm{ZnCo}_{2} \mathrm{O}_{4}$ hollow spheres. It is observed that the discharge specific capacitance gradually increases in the initial 600 cycles. The increase of capacity may be attributed to the activation process for $\mathrm{ZnCo}_{2} \mathrm{O}_{4}$ with high porosity and hollow structure. The highest specific capacitance reaches $1192 \mathrm{~F} \mathrm{~g}^{-1}$, which still remains $1109 \mathrm{~F} \mathrm{~g}^{-1}$ after 2300 cycles, with a capacitance retention rate of $93.11 \%$. The charge-discharge curves of the last five cycles 
have been inserted in Figure 5d. A pair of well-defined charge-discharge plateaus is observed and the curve shapes are similar to those of the initial cycles. The above results further ratify the electrochemical reversibility of the porous $\mathrm{ZnCo}_{2} \mathrm{O}_{4}$ hollow spheres in energy storage applications. Moreover, the as-prepared porous $\mathrm{NiFe}_{2} \mathrm{O}_{4}$ and $\mathrm{ZnSnO}_{3}$ hollow spheres also display promising application as electrode materials for supercapacitors (Figure S6 and S7).
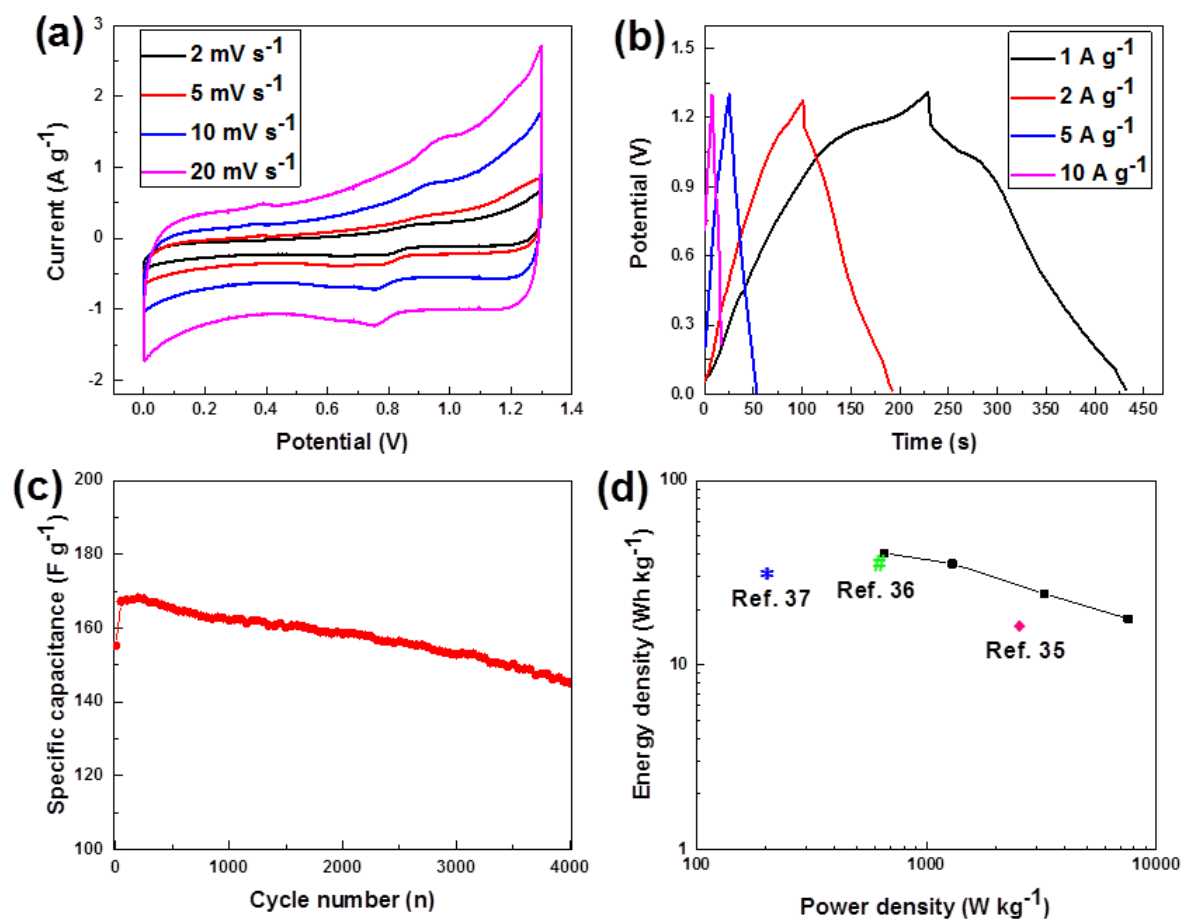

Figure 6. Electrochemical properties of the $\mathrm{ZnCo}_{2} \mathrm{O}_{4} / / \mathrm{AC}$ ASC device. (a) $\mathrm{CV}$ curves at various sweep rates with the working potential window of $1.3 \mathrm{~V}$. (b) Galvanostatic charge-discharge curves with different currents. (c) Cycling performance at $1 \mathrm{~A} \mathrm{~g}^{-1}$. (d) Ragone plots and comparison with the previous reports.

To further evaluate the as-prepared $\mathrm{ZnCo}_{2} \mathrm{O}_{4}$ electrode for practical applications, $\mathrm{ZnCo}_{2} \mathrm{O}_{4} / / \mathrm{AC}$ ASCs are fabricated. The working potential window of the ASC device is $1.3 \mathrm{~V}$ in $2 \mathrm{M} \mathrm{KOH}$. Figure 6a shows the $\mathrm{CV}$ profiles of the assembled $\mathrm{ZnCo}_{2} \mathrm{O}_{4} / / \mathrm{AC}$ at the scan rates of $2 \sim 20 \mathrm{mV} \mathrm{s}^{-1}$. 
Each CV curve displays a cathodic peak and an anodic peak, demonstrating the pseudocapacitive property of $\mathrm{ZnCo}_{2} \mathrm{O}_{4} / / \mathrm{AC}$. Increasing the scan rates, the $\mathrm{CV}$ curves are still stable at $20 \mathrm{mV} \mathrm{s}^{-1}$, demonstrating fast charging and discharging characteristics. The galvanostatic charge-discharge testing of the capacitor was conducted with different currents (Figure 6b). The specific capacitance of $\mathrm{ZnCo}_{2} \mathrm{O}_{4} / / \mathrm{AC}$ achieves $167.7 \mathrm{~F} \mathrm{~g}^{-1}$ at $1 \mathrm{~A} \mathrm{~g}^{-1}$ and it still remains $61.5 \mathrm{~F} \mathrm{~g}^{-1}$ at $10 \mathrm{~A}$ $\mathrm{g}^{-1}$. Figure $6 \mathrm{c}$ shows the cycling stability of $\mathrm{ZnCo}_{2} \mathrm{O}_{4} / / \mathrm{AC}$ at a current density of $1 \mathrm{~A} \mathrm{~g}^{-1}$. The capacitance retention rate is as high as $86.8 \%$ after 4000 cycles. The power performance of $\mathrm{ZnCo}_{2} \mathrm{O}_{4} / / \mathrm{AC}$ is also presented in the Ragone plot. As shown in Figure 6d, the as-prepared $\mathrm{ZnCo}_{2} \mathrm{O}_{4} / / \mathrm{AC}$ delivers an energy density of $39.36 \mathrm{Wh} \mathrm{kg}^{-1}$ at a power density of $650 \mathrm{~W} \mathrm{~kg}^{-1}$ and a power density of $7540 \mathrm{~W} \mathrm{~kg}^{-1}$ at an energy density of $17.8 \mathrm{Wh} \mathrm{kg}^{-1}$, which are higher than previously reported $\mathrm{ZnCo}_{2} \mathrm{O}_{4}$ nanowire//AC, ${ }^{35} \quad \mathrm{ZnCo}_{2} \mathrm{O}_{4} @ \mathrm{MnO}_{2} / / \alpha-\mathrm{Fe}_{2} \mathrm{O}_{3}{ }^{36}$ and $\mathrm{ZnCo}_{2} \mathrm{O}_{4} / \mathrm{PPy} / / \mathrm{PPy}^{37}$

To investigate the structure durability of the as-prepared porous mixed metal oxide hollow spheres, the pristine $\mathrm{ZnCo}_{2} \mathrm{O}_{4}$ electrode and the cycled $\mathrm{ZnCo}_{2} \mathrm{O}_{4}$ electrode are compared in Figure S8. As shown in Figure S8b, after 2000 charge-discharge cycles, the $\mathrm{ZnCo}_{2} \mathrm{O}_{4}$ spheres are not so regular as the pristine electrode, but the sphere-like shape is still maintained well. TEM image shown in Figure S8c demonstrates that even after 2000 cycle at $1 \mathrm{~A} \mathrm{~g}^{-1}$, the $\mathrm{ZnCo}_{2} \mathrm{O}_{4}$ material is still of hollow structure composed of nanoparticles without aggregation, further confirming the good stability of the porous hollow spheres. The good electrochemical properties of the as-prepared $\mathrm{ZnCo}_{2} \mathrm{O}_{4}$ hollow spheres may be due to their following merits: on one hand, the small size, hollow structure, high porosity and ultrathin shells could provide the $\mathrm{ZnCo}_{2} \mathrm{O}_{4}$ material with a large surface area, which implies a large contact area for electrode and electrolyte, and abundant electroactive sites for the redox reactions. On the other hand, they effectively help 
to accelerate the transportation/diffusion of electrons and ions, implying fast kinetics. Furthermore, the cavities resulting from the hollow structure and porous structure could significantly buffer the stress emerged during the electrochemical reaction process. So, their unique structural properties endow the as-obtained $\mathrm{ZnCo}_{2} \mathrm{O}_{4}$ hollow spheres with high discharge capacitance, excellent cycling stability and good rate performance as electrode materials for supercapacitors.

\section{CONCLUSIONS}

In summary, it has been demonstrated that the "ion adsorption-annealing" technique is very effective for synthesizing porous mixed metal oxide hollow spheres with ultrathin shells and high porosity. The unique structure is favorable for sufficient contact between electrode/electrolyte interfaces, thus provide abundant electrochemically active sites and fast

electron and electrolyte ion transportation/diffusion. Last but not least, this structure can maintain well during charge-discharge process. The superior electrochemical performance of such porous $\mathrm{ZnCo}_{2} \mathrm{O}_{4}$ hollow spheres suggests that the porous hollow nanostructures, together with the simple synthesis approach are also expected to be useful in designing other high performance energy storage materials.

\section{ASSOCIATED CONTENT}

Supporting Information. The Supporting Information is available free of charge via the Internet at http://pubs.acs.org. Figures showing the crystal structure, morphology and thermal properties of the as prepared Zn-Co-CSs precursor, Nitrogen adsorption-desorption isotherm, pore size distribution and supercapcitive properties of $\mathrm{NiFe}_{2} \mathrm{O}_{4}$ and $\mathrm{ZnSnO}_{3}$, the EDS spectrum of $\mathrm{ZnCo}_{2} \mathrm{O}_{4}$ and its morphology after long cycles.

\section{AUTHOR INFORMATION}




\section{Corresponding Author}

*E-mail: zguo@uow.edu.au (Z.P.Guo)

*E-mail: wangc@jsnu.edu.cn (C. Wang)

\section{Notes}

The authors declare no competing financial interest.

\section{ACKNOWLEDGMENT}

This work is supported by the National Natural Science Foundation of China (21473081, 21376113) and the Australian Research Council (ARC) (DP1094261 and FT150100109).

\section{REFERENCES}

(1) Wang, G.; Zhang, L.; Zhang, J. A Review of Electrode Materials for Electrochemical Supercapacitors. Chem. Soc. Rev. 2012, 41, 797-828.

(2) Ellis, B. L.; Knauth, P.; Djenizian, T. Three-Dimensional Self-Supported Metal Oxides for Advanced Energy Storage. Adv. Mater. 2014, 26, 3368-3397.

(3) Huang G.; Zhang F.; Du X.; Qin Y.; Yin D.; Wang L. Metal Organic Frameworks Route in Situ Insertion of Multiwalled Carbon Nanotubes in $\mathrm{Co}_{3} \mathrm{O}_{4}$ Polyhedra as Anode Materials for Lithium-Ion Batteries. ACS Nano 2015, 9, 1592-1599.

(4) Xia, X.; Zhang, Y.; Chao, D.; Guan, C.; Zhang, Y.; Li, L.; Ge, X.; Bacho, I. M.; Tu, J.; Fan, H. J. Solution Synthesis of Metal Oxides for Electrochemical Energy Storage Applications. Nanoscale 2014, 6, 5008-5048. 
(5) Wu, H.; Lou, Z.; Yang, H.; Shen, G., A Flexible Spiral-Type Supercapacitor Based on $\mathrm{ZnCo}_{2} \mathrm{O}_{4}$ Nanorod Electrodes. Nanoscale 2015, 7, 1921-1926.

(6) Liu, B.; Liu, B.; Wang, Q.; Wang, X.; Xiang, Q.; Chen, D.; Shen, G. New Energy Storage Option: toward $\mathrm{ZnCo}_{2} \mathrm{O}_{4}$ Nanorods/Nickel Foam Architectures for High-Performance Supercapacitors. ACS Appl. Mater. Interfaces 2013, 5, 10011-10017.

(7) Luo, W.; Hu, X.; Sun, Y.; Huang, Y. Electrospun Porous $\mathrm{ZnCo}_{2} \mathrm{O}_{4}$ Nanotubes as a HighPerformance Anode Material for Lithium-Ion Batteries. J. Mater. Chem. 2012, 22, 8916-8921.

(8) Yu, Z.; Chen, L.; Yu, S. Growth of $\mathrm{NiFe}_{2} \mathrm{O}_{4}$ Nanoparticles on Carbon Cloth for High Performance Flexible Supercapacitors. J. Mater. Chem. A 2014, 2, 10889-10894.

(9) Cherian, C. T.; Sundaramurthy, J.; Reddy, M. V.; Kumar, P. S.; Mani, K.; Pliszka, D.; Sow, C. H.; Ramakrishna, S.; Chowdari, B. V. R. Morphologically Robust $\mathrm{NiFe}_{2} \mathrm{O}_{4}$ Nanofibers as High Capacity Li-Ion Battery Anode Material. ACS Appl. Mater. Interfaces 2013, 5, 9957-9963.

(10) Wang, Z.; Zhang, X.; Li, Y.; Liu, Z.; Hao, Z. Synthesis of Graphene- $\mathrm{NiFe}_{2} \mathrm{O}_{4}$ Nanocomposites and Their Electrochemical Capacitive Behaviour. J. Mater. Chem. A 2013, 1, 6393-6399.

(11) Han, F; Li, W; Lei, C; He, B; Oshida, K; Lu A. Selective Formation of Carbon-Coated, Metastable Amorphous $\mathrm{ZnSnO}_{3}$ Nanocubes Containing Mesopores for Use as High-Capacity Lithium-Ion Battery. Small 2014, 10, 2637-2644.

(12) Hong, Y. J.; Kang, Y. C. Formation of Core-Shell-Structured $\mathrm{Zn}_{2} \mathrm{SnO}_{4}$-Carbon Microspheres with Superior Electrochemical Properties by One-Pot Spray Pyrolysis. Nanoscale 2015, 7, 701-707. 
(13) Yuan, C.; Wu, H. B.; Xie, Y.; Lou, X. W. Mixed Transition-metal Oxides: Design, Synthesis, and Energy-Related Applications. Angew. Chem., Int. Ed. 2014, 53, 1488-1450.

(14) Sharma, Y.; Sharma, N.; Rao, G. V. S.; Chowdari, B. V. R. Nanophase $\mathrm{ZnCo}_{2} \mathrm{O}_{4}$ as a High Performance Anode Material for Li-Ion Batteries, Adv. Funct. Mater. 2007, 17, 2855-2861.

(15) Guo, L.; Ru, Q.; Song, X.; Hu, S.; Mo, Y. Mesoporous $\mathrm{ZnCo}_{2} \mathrm{O}_{4}$ Microspheres as an Anode Material for High-Performance Secondary Lithium Ion Batteries. RSC Adv. 2015, 5, 19241-19247.

(16) Liu, X.; Shi, S.; Xiong, Q.; Li, L.; Zhang, Y.; Tang, H.; Gu, C.; Wang, X.; Tu, J. Hierarchical $\mathrm{NiCo}_{2} \mathrm{O}_{4} @ \mathrm{NiCo}_{2} \mathrm{O}_{4} \quad$ Core/Shell Nanoflake Arrays as High-Performance Supercapacitor Materials. ACS Appl. Mater. Interfaces 2013, 5, 8790-8795.

(17) Wang, Q.; Du, J.; Zhu, Y.; Yang, J.; Chen, J.; Wang, C.; Li, L.; Jiao, L. Facile Fabrication and Supercapacitive Properties of Mesoporous Zinc Cobaltite Microspheres. J. Power Sources 2015, 284, 138-145.

(18) Qiu, Y.; Yang, S.; Deng, H.; Jin, L.; Li, W. A Novel Nanostructured Spinel $\mathrm{ZnCo}_{2} \mathrm{O}_{4}$ Electrode Material: Morphology Conserved Transformation from A Hexagonal Shaped Nanodisk Precursor and Application in Lithium Ion Batteries. J. Mater. Chem. 2010, 20, 44394444.

(19) Wang, Q.; Zhu, L.; Sun, L.; Liu, Y.; Jiao, L. Facile synthesis of hierarchical porous $\mathrm{ZnCo}_{2} \mathrm{O}_{4}$ microspheres for high-performance supercapacitors. J. Mater. Chem. A 2015, 3, 982985. 
(20) Chen, Y.; Qu, B.; Mei, L.; Lei, D.; Chen, L.; Li, Q.; Wang, T. Synthesis of $\mathrm{ZnSnO}_{3}$

Mesocrystals from Regular Cube-Like to Sheet-Like Structures and Their Comparative Electrochemical Properties in Li-Ion Batteries. J. Mater. Chem. 2012, 22, 25373-25379.

(21) Bao, F.; Wang, X.; Zhao, X.; Wang, Y.; Ji, Y.; Zhang, H.; Liu, X. Controlled Growth of Mesoporous $\mathrm{ZnCo}_{2} \mathrm{O}_{4}$ Nanosheet Arrays on $\mathrm{Ni}$ Foam as High-Rate Electrodes for Supercapacitors. RSC Adv. 2014, 4, 2393-2397.

(22) Wang, S.; Pu, J.; Tong, Y.; Cheng, Y.; Gao, Y.; Wang, Z. $\mathrm{ZnCo}_{2} \mathrm{O}_{4}$ Nanowire Arrays Grown on Nickel Foam for High-Performance Pseudocapacitors. J. Mater.Chem. A 2014, 2, 5434-5440.

(23) Cheng, J.; Lu, Y.; Qiu, K.; Yan, H.; Hou, X.; Xu, J.; Han, L.; Liu, X.; Kim, J. K.; Luo, Y. Mesoporous $\mathrm{ZnCo}_{2} \mathrm{O}_{4}$ Nanoflakes Grown on Nickel Foam as Electrodes for High Performance Supercapacitors. Phys. Chem. Chem. Phys. 2015, 17, 17016-17022.

(24) Ge, J.; Fan, G.; Si, Y.; He, J.; Kim, H.; Ding, B.; Al-Deyab, S. S.; El-Newehy, M.; Yu, J. Elastic and Hierarchical Porous Carbon Nanofibrous Membranes Incorporated with $\mathrm{NiFe}_{2} \mathrm{O}_{4}$ Nanocrystals for Highly Efficient Capacitive Energy Storage. Nanoscale 2016, 8, 2195-2204.

(25) Liu, B.; Wang, X.; Liu, B.; Wang, Q.; Tan, D.; Song, W.; Hou, X.; Chen, D.; Shen, G. Advanced Rechargeable Lithium-Ion Batteries Based on Bendable $\mathrm{ZnCo}_{2} \mathrm{O}_{4}$-Urchins-onCarbon-Fibers Electrodes. Nano Res. 2013, 6, 525-534.

(26) Deng, Y.; Zhang, Q.; Tang, S.; Zhang, L.; Deng, S.; Shi, Z.; Chen, G. One-Pot Synthesis of $\mathrm{ZnFe}_{2} \mathrm{O}_{4} / \mathrm{C}$ Hollow Spheres as Superior Anode Materials for Lithium Ion Batteries. Chem. Commun. 2011, 47, 6828-6830. 
(27) Lou, X. W.; Lynden A, A.; Yang, Z. Hollow Micro-/Nanostructures: Synthesis and Applications. Adv. Mater. 2008, 20, 3987-4019.

(28) Hu, J.; Chen, M.; Fang, X.; Wu, L. Fabrication and Application of Inorganic Hollow Spheres. Chem. Soc. Rev. 2011, 40, 5472-5491.

(29) Guo, H.; Li, T.; Chen, W.; Liu, L.; Yang, X.; Wang, Y.; Guo, Y., General Design of Hollow Porous $\mathrm{CoFe}_{2} \mathrm{O}_{4}$ Nanocubes from Metal-Organic Frameworks with Extraordinary Lithium Storage. Nanoscale 2014, 6, 15168-15174.

(30) Lai, X.; Halpert, J. E.; Wang, D. Recent Advances in Micro-/Nano-Structured Hollow Spheres for Energy Applications: from Simple to Complex Systems. Energy Environ. Sci. 2012, $5,5604-5618$.

(31) Wang, J.; Yang, N.; Tang, H.; Dong, Z.; Jin, Q.; Yang, M.; Kisailus, D.; Zhao, H.; Tang, Z.; Wang, D. Accurate Control of Multishelled $\mathrm{Co}_{3} \mathrm{O}_{4}$ Hollow Microspheres as HighPerformance Anode Materials in Lithium-Ion Batteries. Angew. Chem., Int. Ed. 2013, 52, 64176420.

(32) Zhang, G.; Lou, X. General Synthesis of Multi-Shelled Mixed Metal Oxide Hollow Spheres with Superior Lithium Storage Properties. Angew. Chem. 2014, 126, 9187-9190.

(33) Tian, Z.; Zhou, Y.; Li, Z.; Liu, Q.; Zou, Z. Generalized Synthesis of a Family of Multishelled Metal Oxide Hollow Microspheres. J. Mater. Chem. A 2013, 1, 3575-3579.

(34) Maria-Magdalena, T.; Markus, A.; Arne, T. A Generalized Synthesis of Metal Oxide Hollow Spheres Using a Hydrothermal Approach. Chem. Mater. 2006, 18, 3808-3812. 
(35) Guan, B.; Guo, D.; Hu, L.; Zhang, G.; Fu, T.; Ren, W.; Li, J.; Li, Q. Facile Synthesis of $\mathrm{ZnCo}_{2} \mathrm{O}_{4}$ Nanowire Cluster Arrays on $\mathrm{Ni}$ Foam for High-Performance Asymmetric Supercapacitors. J. Mater. Chem. A 2014, 2, 16116-16123.

(36) Ma, W.; Nan, H.; Gu, Z.; Geng, B.; Zhang, X. Superior Performance Asymmetric Supercapacitors Based on $\mathrm{ZnCo}_{2} \mathrm{O}_{4} @ \mathrm{MnO}_{2}$ Core-Shell Electrode. J. Mater. Chem. A 2015, 3, $5442-5448$.

(37) Chen, T.; Fan, Y.; Wang, G.; Yang, Q.; Yang, R. Rationally Designed Hierarchical $\mathrm{ZnCo}_{2} \mathrm{O}_{4} /$ Polypyrrole Nanostructures for High-Performance Supercapacitor Electrodes. RSC $A d v .2015,5,74523-74530$. 


\section{Table of Contents Graphic}

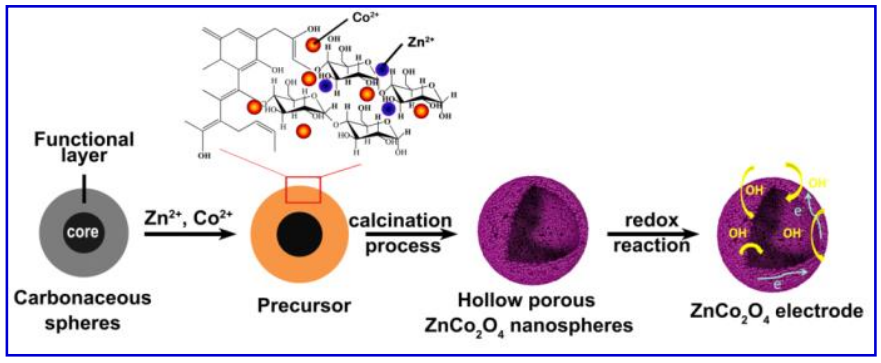




\section{Supporting Information}

\section{General Synthesis of Porous Mixed Metal Oxide Hollow Spheres with Enhanced Supercapacitive Properties}

Qinghong Wang, ${ }^{\mathrm{a}, \mathrm{b}}$ Yuxuan Zhu, ${ }^{\mathrm{a}}$ Jing Xue, ${ }^{\mathrm{a}}$ Xinsheng Zhao, ${ }^{\mathrm{c}}$ Zaiping Guo, ${ }^{\mathrm{b},{ }^{*}}$ Chao Wang,

${ }^{\text {a }}$ School of Chemistry and Chemical Engineering, Jiangsu Key Laboratory of Green Synthetic Chemistry for Functional Materials, Jiangsu Normal University, Xuzhou, Jiangsu 221116, China.

Email: wangc@jsnu.edu.cn

${ }^{\mathrm{b}}$ Institute for Superconducting \& Electronic Materials, University of Wollongong, Wollongong, NSW 2522, Australia. Email: zguo@uow.edu.au

${ }^{\mathrm{c}}$ Hydrogen energy laboratory, School of Physics and Electronic Engineering, Jiangsu Normal University, Xuzhou, Jiangsu 221116, China 
Figure S1. XRD patterns of carbohydrate spheres and the Zn-Co-CSs precursor.

Figure S2. (a, b) SEM images of carbohydrate spheres; (c, d) SEM images of the Zn-Co-CSs precursor.

Figure S3. TGA curve of the Zn-Co-CSs precursor.

Figure S4. EDS spectrum of the as-prepared porous $\mathrm{ZnCo}_{2} \mathrm{O}_{4}$ hollow spheres.

Figure S5. Nitrogen adsorption-desorption isotherm and the corresponding pore size distribution of the asprepared samples: (a, b) porous $\mathrm{NiFe}_{2} \mathrm{O}_{4}$ hollow spheres, (c, d) $\mathrm{ZnSnO}_{3}$ hollow spheres.

Figure S6. Electrochemical properties of the porous $\mathrm{NiFe}_{2} \mathrm{O}_{4}$ hollow spheres electrode: (a) CV curves at different scan rates, (b) galvanostatic charge-discharge curves at different current densities, (c) rate performance, and (d) cycle life. The inset of is the charge-discharge curves of the last 5 cycles.

Figure S7. $\mathrm{CV}$ curves of $\mathrm{ZnSnO}_{3}$ electrode at different scan rates in $1 \mathrm{M} \mathrm{Na}_{2} \mathrm{SO}_{4}$ aqueous electrolyte.

Figure S8. (a) SEM image of the pristine $\mathrm{ZnCo}_{2} \mathrm{O}_{4}$ electrode, (b) SEM image and (c) TEM image of the cycled $\mathrm{ZnCo}_{2} \mathrm{O}_{4}$ electrode after 2000 cycles at $1 \mathrm{~A} \mathrm{~g}^{-1}$. 


\section{Supercapacitive properties of the as-prepared $\mathrm{NiFe}_{2} \mathrm{O}_{4}$ electrode and $\mathrm{ZnSnO}_{3}$ electrode}

The capacitive performance of the as-obtained $\mathrm{NiFe}_{2} \mathrm{O}_{4}$ and $\mathrm{ZnSnO}_{3}$ hollow spheres were also investigated in three-electrode system in $2 \mathrm{M} \mathrm{KOH}$ and $1 \mathrm{M} \mathrm{Na}_{2} \mathrm{SO}_{4}$ aqueous electrolyte, respectively. From Figure S6a, it can be seen that the voltammetric currents of $\mathrm{NiFe}_{2} \mathrm{O}_{4}$ electrode increase with the scan rate, showing the behavior similar to that of an ideal capacitor. $^{[1]}$ The specific capacitances were calculated from the corresponding galvanostatic discharge curves (Figure S6b) in the range of $-1.0 \mathrm{~V}$ to $0 \mathrm{~V}$ at various current densities. The values of specific capacitances for $\mathrm{NiFe}_{2} \mathrm{O}_{4}$ composite are $220.1 \mathrm{~F} \mathrm{~g}^{-1}$ at $1 \mathrm{~A} \mathrm{~g}^{-1}, 186.7 \mathrm{~F} \mathrm{~g}^{-1}$ at $2 \mathrm{~A} \mathrm{~g}^{-1}, 137.9 \mathrm{~F} \mathrm{~g}^{-1}$ at $5 \mathrm{~A} \mathrm{~g}^{-1}$ and $134.6 \mathrm{~F} \mathrm{~g}^{-1}$ at $10 \mathrm{~A} \mathrm{~g}^{-1}$, respectively. The cycle stability of the as-prepared $\mathrm{NiFe}_{2} \mathrm{O}_{4}$ electrode was tested by performing continuous charge-discharge cycles at a constant discharge current density of $1 \mathrm{Ag}^{-1}$. As shown in Figure $\mathrm{S} 6 \mathrm{~d}$, the $\mathrm{NiFe}_{2} \mathrm{O}_{4}$ electrode shows high specific capacitance of $262.2 \mathrm{~F} \mathrm{~g}^{-1}$ and it still remains $181.7 \mathrm{~F} \mathrm{~g}^{-1}$ after 2000 cycles, with the capacity retention rate of $69.4 \%$, showing good cycle stability of the asprepared $\mathrm{NiFe}_{2} \mathrm{O}_{4}$.

Figure S7 shows that the electrochemical behavior of $\mathrm{ZnSnO}_{3}$ electrode is also similar to ideal capacitor and it delivers specific capacitance of $58.6 \mathrm{~F} \mathrm{~g}^{-1}$ at $5 \mathrm{mV} \mathrm{s}^{-1}, 35.5 \mathrm{~F} \mathrm{~g}^{-1}$ at 10 $\mathrm{mV} \mathrm{s}^{-1}$ and $25.2 \mathrm{~F} \mathrm{~g}^{-1}$ at $20 \mathrm{mV} \mathrm{s}^{-1}$.

[1] Kumbhar, V.S.; Jagadale, A.D.; Shinde, N.M.; Lokhande, C.D. Chemical synthesis of spinel cobalt ferrite $\left(\mathrm{CoFe}_{2} \mathrm{O}_{4}\right)$ nano-flakes for supercapacitor application. Appl. Surf. Sci. 2012, 259, 39-43. 


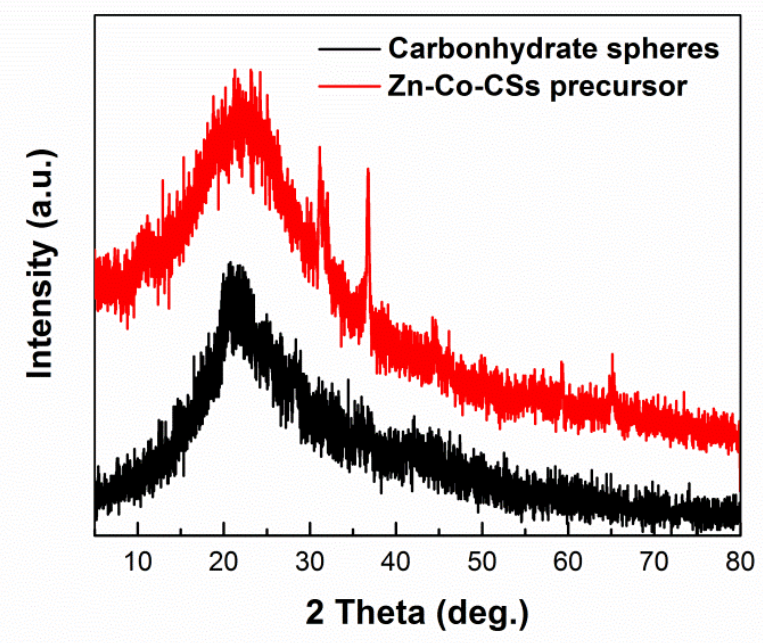

Figure S1. XRD patterns of carbohydrate spheres and the Zn-Co-CSs precursor.
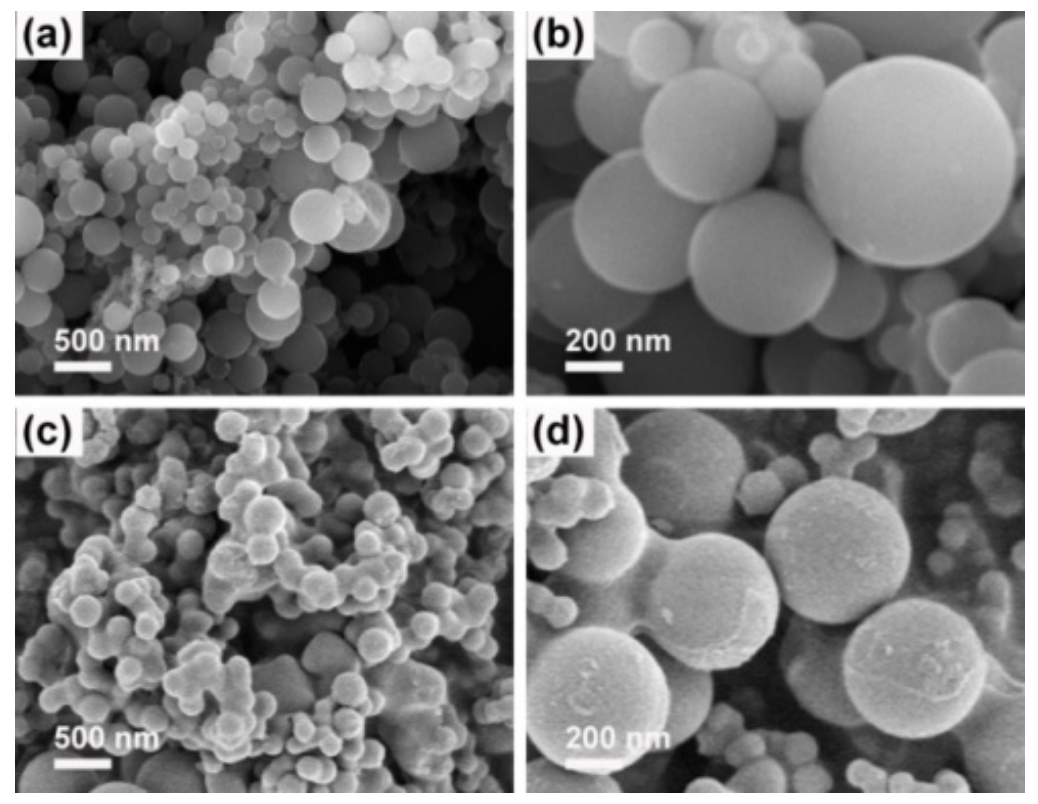

Figure S2. (a, b) SEM images of carbohydrate spheres; (c, d) SEM images of the Zn-Co-CSs precursor. 


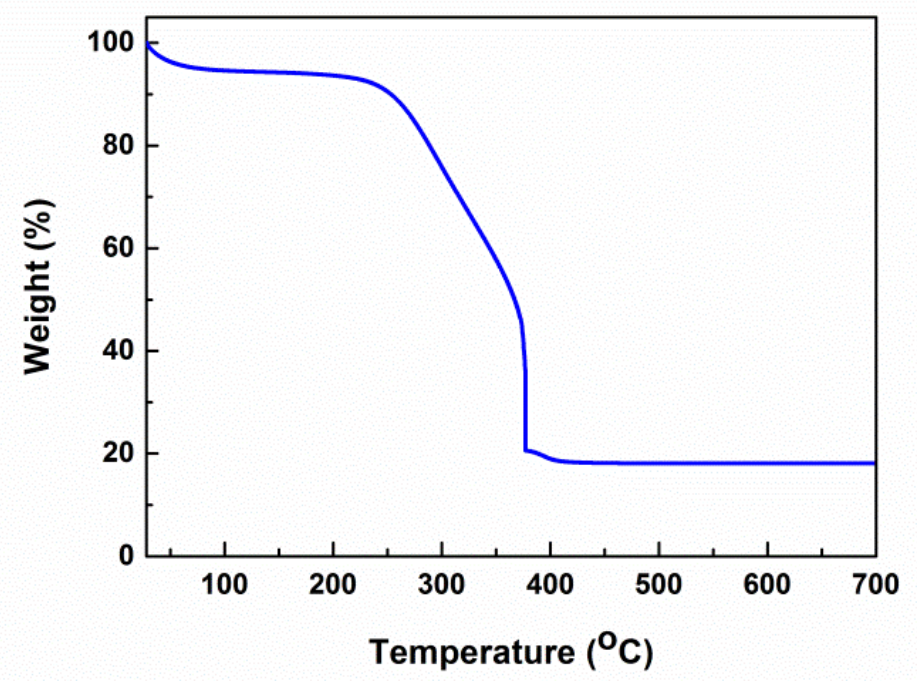

Figure S3. TGA curve of the Zn-Co-CSs precursor.

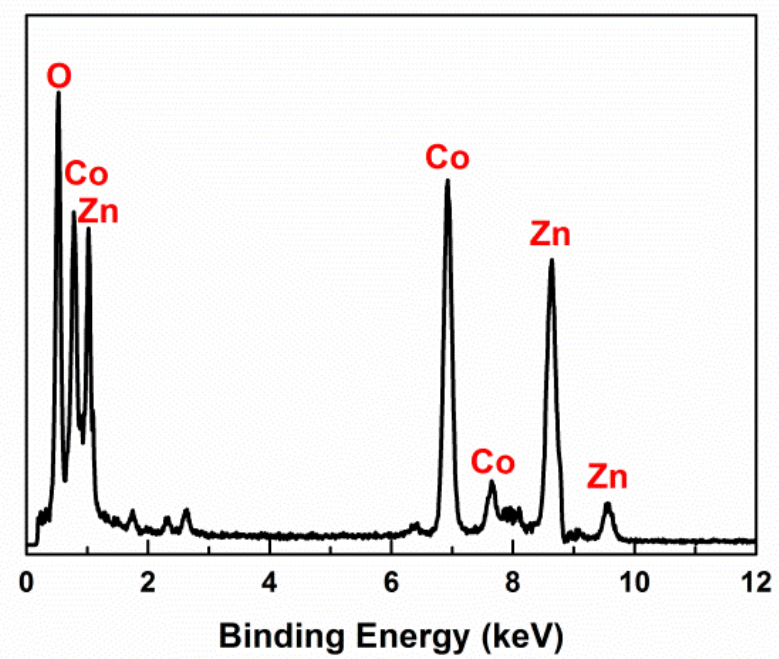

Figure S4. EDS spectrum of the as-prepared porous $\mathrm{ZnCo}_{2} \mathrm{O}_{4}$ hollow spheres. 

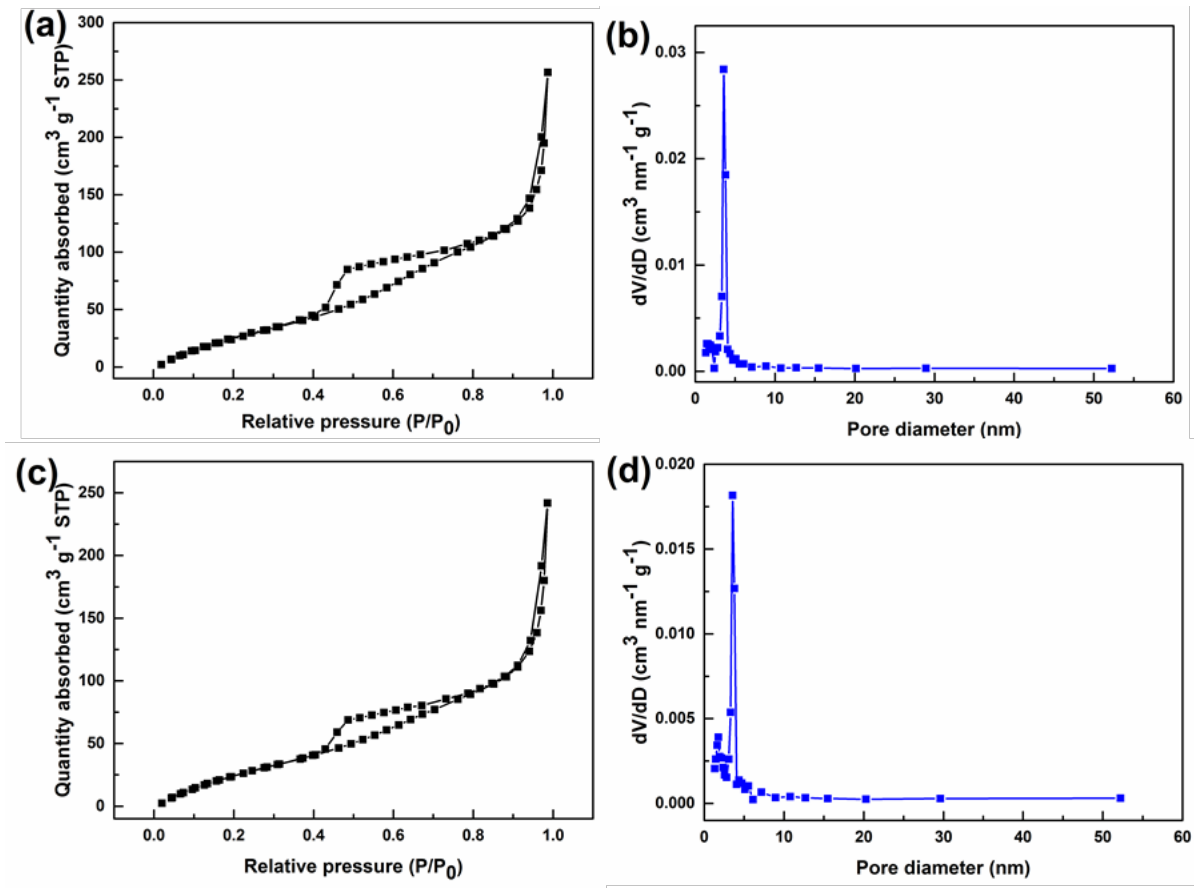

Figure S5. Nitrogen adsorption-desorption isotherm and the corresponding pore size distribution of the as-prepared samples: (a, b) porous $\mathrm{NiFe}_{2} \mathrm{O}_{4}$ hollow spheres, (c, d) $\mathrm{ZnSnO}_{3}$ hollow spheres. 

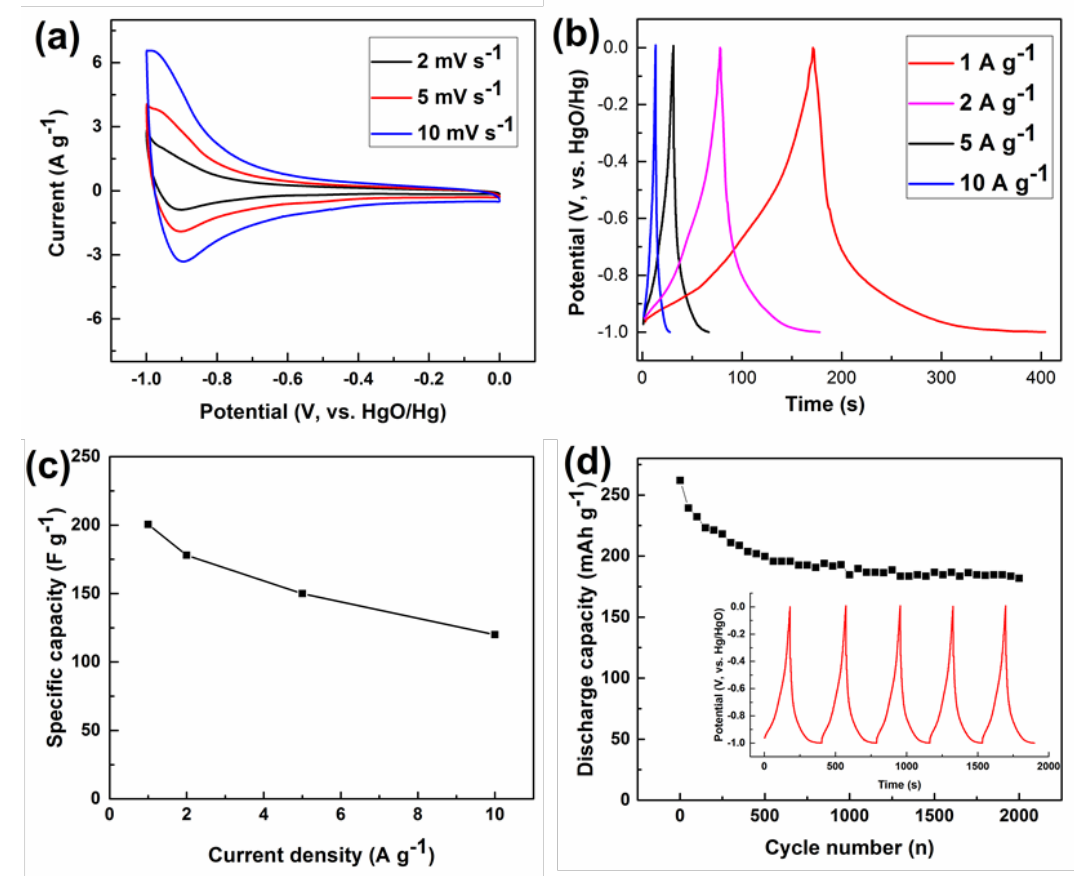

Figure S6. Electrochemical properties of the porous $\mathrm{NiFe}_{2} \mathrm{O}_{4}$ hollow spheres electrode: (a)

CV curves at different scan rates, (b) galvanostatic charge-discharge curves at different current densities, (c) rate performance, and (d) cycle life. The inset of is the charge-discharge curves of the last 5 cycles.

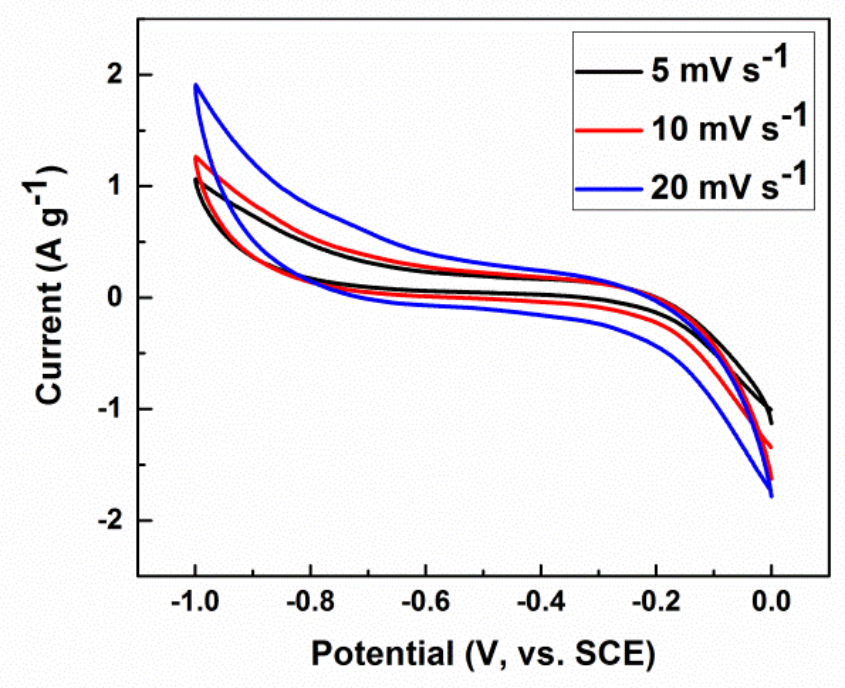

Figure S7. $\mathrm{CV}$ curves of $\mathrm{ZnSnO}_{3}$ electrode at different scan rates in $1 \mathrm{M} \mathrm{Na}_{2} \mathrm{SO}_{4}$ aqueous electrolyte. 


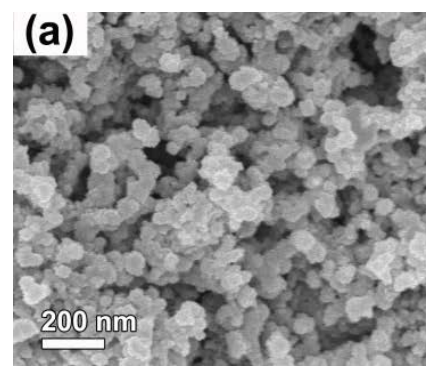

(b)

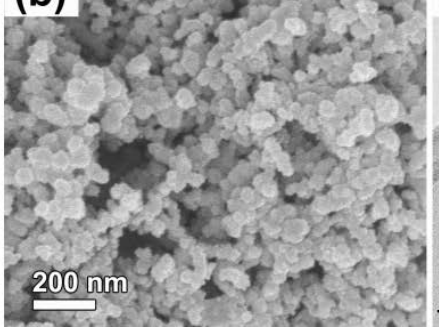

(c) $100 \mathrm{~nm}$

Figure S8. (a) SEM image of the pristine $\mathrm{ZnCo}_{2} \mathrm{O}_{4}$ electrode, (b) SEM image and (c) TEM image of the cycled $\mathrm{ZnCo}_{2} \mathrm{O}_{4}$ electrode after 2000 cycles at $1 \mathrm{~A} \mathrm{~g}^{-1}$. 